\title{
Evaluation of Preschool Education Program According to CIPP Model
}

\author{
Mehmet Basaran ${ }^{1 \star}$, Busra Dursun ${ }^{1}$, Hatice Damla Gur Dortok ${ }^{1}$, Gokhan Yilmaz ${ }^{1}$
}

${ }^{1}$ Gaziantep University, TURKEY

*Corresponding Author: mehmetbasarn@gmail.com

Citation: Basaran, M., Dursun, B., Gur Dortok, H. D., \& Yilmaz, G. (2021). Evaluation of Preschool Education Program According to CIPP Model. Pedagogical Research, 6(2), em0091. https://doi.org/10.29333/pr/9701

\section{ARTICLE INFO}

Received: 26 Oct. 2020

Accepted: 3 Dec. 2020

\begin{abstract}
The main purpose of the research is the evaluation of the pre-school education program according to CIPP (context, input, process, and product) model belongs to Stufflebeam. Parallel design form mixed research methods was used in the research. Quantitative data of the research were collected from 122 preschool teachers working in public or private schools in 2019 - 2020 academic years. Qualitative data were collected from 10 preschool teachers via an online interview with the help of a semi-structured interview form. In the research, 'Preschool Education Program Evaluation Scale' and 'semi-structured interview forms' prepared by the researchers were used as data collection tools. As a result of the study, it was revealed that the teachers stated the most negative opinions in the context dimension. Teachers stated that there is not enough equipment to organize learning centers in this dimension, and the physical characteristics of schools are not sufficient for pre-school education. Although generally positive opinions were expressed in the input dimension, it was revealed that the individual differences of the children and the family factor were not taken into account in the program. Finally, when we look at the product dimension, it was stated by the teachers that preschool education facilitates the school orientation of children and is effective in preparing children for primary school, but pre-school education is not effective in solving the problems arising from the family.
\end{abstract}

Keywords: preschool education program, program evaluation, Stufflebeam CIPP Model

\section{INTRODUCTION}

As soon as individuals open their eyes to the world, they make an effort to learn. He has a desire to learn by questioning his surroundings with his innate sense of curiosity. However, if this desire of individuals is not supported by stimuli, unfortunately, this learning effort will not take long. While this curiosity and desire to learn is the duty of caregivers in the first years of life, many efforts are made to carry out this work in a more systematic way later on. Education, which was the task of the family, in the beginning, became more systematic and societies took responsibility in this regard (Oral \& Yazar, 2017). This occupation was a factor that brought out the concept of education. According to Tyler, education is the process of changing one's behavior with learning experiences similar to real-life experiences in many respects (Erişen, 1998). Ertürk (2013) defined the process of changing an individual's behavior intentionally and deliberately through their experiences as education. Dewey focused on education as the individual interrogation by experiences (Glassman, 2001). According to another definition, education is planned effects that provide certain improvements in people's behavior based on predetermined principles (Arslan, 2009). Training programs are organized from an early age to make sense of this learning effort, not to lose the desire and curiosity to learn. The educational program has been described by many people in the literature. Demirel (2017) defined the order of educational activities that take place at school or anywhere as an education program. According to Bobbit; Planned and unplanned experiences to reveal the skills of individuals or a planned set of teaching experiences required for the development of individuals are defined as an educational program (Oral \& Yazar, 2017). Bobbit underlines that the targets should be determined well for the realization of efficiency in the educational program (Aktan, 2015). If an educational program will be planned, the targets should be well determined. If educators will study systematically, educational targets will be guaranteed (Sarangapani, 2006). All this planned education is possible with preschool education activities at an early age, most healthily and efficiently.

Pre-school education is a period that covers early childhood. Exposure to rich stimuli by the family in the first years of life has a great influence on the extent to which a child can develop or not. The child's future personality, attitudes, and beliefs are shaped by the interactions they experience during this period (Yaşar Ekici, 2017). According to neurobiological and behavioral perspectives, the constitution of values and character and basic personality and intellectual development is realized up to age 7 . Hence, nurturing the environment process is crucial for the success or failure of future life (Nance, 2009). Postnatal 0 - 6 years is the fastest development period of the child. Early childhood is the most important year of development and the fastest development. According to Bloom; Cognitive development is most important in the first four years. It is stated that half of the 
human intelligence between 0 and 4 years old, two-thirds of the half between 4 and 8 years old, and the rest between 8 and 17 years old develop (Aydoğan, 2006). In the preschool period, many connections are made in the brain. While connections supported by stimuli continue to be established, unused connections are unfortunately lost.

A solid foundation for the child's cognitive, language, motor, social and emotional development is provided by brain development. For this reason, children grow very rapidly in the first six years of life, namely in the preschool period, and gain competence at an astonishing rate in all areas of development (Ministry of Education, 2013). When we consider language development, early childhood is a critical period. Researchers argue that a lag in language structure during childhood can affect all life (Kol, 2011). Considering that development is holistic, it is possible to say similar things for all development areas. Pre-school education is of great importance to ensure that this education, which started in the family, continues under equal conditions for all children. Preschool education comes to the fore for children from different socio-economic backgrounds to achieve equality of opportunity in education. A government giving importance to equality should compensate for different conditions of children (Currie, 2001).

It is now clearly known that children who have completed pre-school education have a positive approach when starting primary school. Preschool education has many positive effects on children. It was determined that children who took pre-school education and started primary school were successful by gaining competence in areas such as reading-writing, mathematics, and cooperation. Also, it was observed that they developed important emotions such as helpfulness, creativity, and responsibility (Mother and Child Education Foundation, 2003). With pre-school education, stimulants with rich content offered in educational environments, individuals have the opportunity to compare new learning with their previous learning, establish relationships, and create new knowledge. Besides, preschool education can have significant effects on the development of academic, social, language, psycho-motor, and self-care skills of children, especially disadvantaged children (Aslan \& Uygun, 2019). On the other side, the preschool education program has positive effects on governments' economy. According to a special conference conducted by the MIT Workplace Center and the Legal Momentum Family Initiative for purposes of studying the Economic Impacts of Child Care and Early Education in 2004, for every dollar spent on Early Childhood Education, the taxpayer saves $\$ 13$ in public education, criminal justice, and welfare costs over the next 20 years, which exceeds the rate of return on most other economic development programs (Nance, 2009). The development of all these is possible with the implementation of a good planned preschool education.

Pre-school education in Turkey, 36 - 72 months includes the children's education. The aims and duties of pre-school education are stated as ensuring the physical, mental, and emotional development of children and acquiring good habits, preparing them for primary school education, creating a common upbringing environment for disadvantaged children, and ensuring that children speak Turkish correctly and well (MoNE, 2013). Through the rich and active learning experiences of children attending pre-school education institutions; a pre-school education program has been developed to ensure that their development reaches the highest level in the areas of motor, social and emotional, language, and cognitive development, that they gain self-care skills and that they are ready for primary school education (MoNE, 2013). This program prepared by the Ministry of National Education, is flexible and spiral, has the characteristic of being balanced and game-based prioritizes learning by discovering, cares about the development of creativity, cares about daily life experiences and family participation, and has adopted a versatile evaluation process.

The program is based on achievements and indicators (MoNE, 2013). Examples are presented in the program where daily and monthly plans are prepared by teachers according to the characteristics of the group.

It is very important to what extent the program being implemented serves the purpose. The most important way to determine this is to evaluate that program. As a concept, evaluation is the process of measuring whether an available data or product serves the purpose and its functionality in the field. In education, this concept is to make evaluative judgments by making qualitative or quantitative distinctions about the features that the programs should have to serve the purpose.

Evaluation is the review of existing models, programs, inputs, or stages of program designs and the restoration and renewal of the service evaluated with the recommendations obtained in line with this result. In its deepest sense, program evaluation is defined as "the process of deciding about the effectiveness of the program, determining the final stage of program development and the realization degree of educational goals" according to Ertürk (1997) (cited in Akdağ, 2008, 26). Program evaluation is an integral part of the education process. It gives information about the success of the training program and compares it according to a criterion and a meaningful result is reached. Different objectives such as the development of a program or application, providing evidence about the efficiency and effectiveness obtained from the implementation can be achieved through program evaluation (Klenowski, 2010). Program evaluation is necessary when new interventions are being tried or there is a belief that the program should be developed (Royce, \& et al, 2009). In this way, it is decided whether the evaluated training program will remain in the education system or not. By taking part in the last stage of the program development process, it provides the relationship, vitality, and mobility between the other steps.

The differences in the goals and forms of the programs and models have diversified the program evaluation step. Stufflebeam and Corny (2014, p. 45-46) attribute this program and model redundancy and the lack of highly applicable models to the relative innovation of science and their focus on developing the methods and materials they will still use. Based on this information, in a short and concise form; Assessment is a multi-faceted concept, with features such as selecting, obtaining, and then analyzing, improving, using the information to be measured, and deciding on the quality and efficiency of the program (Karataş, 2007). Determining whether the implemented program has achieved its goals will increase the functionality of that program and allow it to be revised where it needs to be regulated. It is very important to get opinions from the program's practitioners, namely teachers, on this issue. There are many program evaluation approaches. In this study, the Context, Input, Process, and Product (CIPP) model proposed by Stufflebeam will be used. In this research, this model was used because evaluation has an ongoing nature and to handle the pre-school education program in a versatile and comprehensive way (Sholihah, Purnawirawan, \& Puspita, 2020). 
Whichever evaluation approach it is based on, when evaluating a training program, a curriculum evaluation model must be based. Evaluating a program is not only revealing the pros and cons of that program but also identifying and correcting the disconnections between the parts in this dynamic system. Since program evaluation involves very detailed processes, the evaluation must be done systematically and holistically (Koçak, 2006, p. 38). Program evaluation is related to supplementary contributions of a series of instructional components (Steele, 1975).

It is a widely used program evaluation model (CIPP), which consists of context size, input size, process size, and product dimensions proposed by Stufflebeam. This evaluation model consists of four situations. To arrive at a meaningful assessment, the available data are correlated in each case in the context of various frameworks. Stufflebeam's program evaluation model contains more than one meaning within its sub-branches. According to the Stufflebeam approach, the goal is to inform evaluators. With this information, the four phases of the program are evaluated according to these decisions by those who are authorized to make decisions.

The first element that constitutes the evaluation model, context, is the analysis of the desired and existing situations related to the general lines of the program. The tasks to be fulfilled at this stage start with the needs analysis. Following this, it includes determining the program objectives and determining how these goals are followed. Context evaluation is very effective in the planning process. It has an important role in determining the consistency and consistency of program needs, goals, and resources, and the adequacy of goals in solving problems (Fitzpatrick et al., 2004). In input evaluation, it is the process of deciding how activities will be used to achieve the specified goals of the program. The suitability, cost, and potential of resources are evaluated at this stage. Questions about whether the targets are determined appropriately whether they are compatible with the program or strategy compatibility are sought. In the process element, it is the field, which is the implementation phase, of program development and evaluation. The purpose of this evaluation is to determine the compatibility between desired situations and existing situations. In order not to encounter any problems during the implementation phase of the program, this stage provides an opportunity to prevent these problems. The questions such as whether the studies determined in the program are carried out in the estimated time or whether these activities were carried out by the plan are answered. In product evaluation, it is the stage of evaluating the outputs achieved at the end of the program. It is the evaluation in which the data in the applied program, that is, the products are examined. The operability of the program and the gains obtained from the program are evaluated. An answer is sought for the question of whether the desired or intended results have been achieved in the program.

In this context, in this study, an answer was sought to the question of what are the opinions of preschool teachers in terms of context, input, process, and product?

\section{METHOD}

\section{Research Design}

In this study, a mixed research method, in which qualitative and quantitative research methods are used together. The explanatory sequential design is used from mixed-method designs. According to Clark (as cited in Subedi, 2016), the explanatory sequential design is composed of quantitative data and qualitative data separately. Quantitative data is explained deeply by qualitative data. Firstly, quantitative data should be collected. Then qualitative data should be supported by qualitative data. While the quantitative research method provides access to a large number of participants in terms of its application, it enables the data collection from many people, while the data obtained with the help of qualitative data collection methods provide in-depth data allowing the subject of the study to be examined in detail (Green et al., 2005). In the quantitative dimension of the research, the survey study was applied, one of the survey methods. A scanning method is an approach that aims to describe a situation that has existed before or still exists without changing it. The event, individual, or object, which is the subject of research, is tried to be defined under the conditions and as it is. General screening; is called the scans made on the whole of the universe or the sample is taken from the universe reaches a general judgment about the universe (Karasar, 2016). The qualitative research approach is a kind of scientific study and consists of a series of studies that collect open-ended questions (Creswell, 2013). In the qualitative dimension of the research, interviews were conducted and content analysis was applied. The stages used in the content analysis are; conceptualizing and coding data, finding themes, organizing codes and themes, defining and interpreting the findings (Yıldııı \& Şimşek 2018). The research started with collecting quantitative data and after that the qualitative data collected to support quantitative data and to determine the opinions of preschool teachers.

\section{Study Group}

In the quantitative dimension of the research; while the sample of 122 pre-school teachers working in the 2019-2020 academic year in public and private schools, constitutes 10 volunteer pre-school teachers available in the qualitative dimension. The convenience sampling method was preferred as the sample type in the study. Teachers were reached from a close circle, via Facebook, blog, and social media groups. The online scales prepared over the Google docs infrastructure were sent to teachers to fill them in, and online interviews were made with 10 preschool teachers.

As seen in Table 1, 99 of 122 preschool teachers participating in the study are women and 23 are men. In terms of their tenure, there are 83 teachers with 1 to 5 years of experience, 23 with 6 to 10 years of experience, 12 with 11 to 15 years of experience, and 4 teachers with 16 to 20 years of experience. 113 of the teachers are undergraduate and 9 are graduates of a postgraduate program. 115 teachers work in a public school and 7 teachers work in a private school. 
Table 1. Demographic Information of Teachers

\begin{tabular}{|c|c|c|c|}
\hline Demographic variable & Category & Number (n) & Percent (\%) \\
\hline \multirow{2}{*}{ Gender } & Female & 99 & 81.1 \\
\hline & Male & 23 & 18.9 \\
\hline \multirow{4}{*}{ Tenure } & 1-5 year & 83 & 68 \\
\hline & 6-10 year & 23 & 18.9 \\
\hline & $11-15$ year & 12 & 9.8 \\
\hline & $16-20$ year & 4 & 3.3 \\
\hline \multirow{2}{*}{ Graduation } & Undergraduate & 113 & 92.6 \\
\hline & Postgraduate & 9 & 7.4 \\
\hline \multirow{2}{*}{ School Type } & State school & 115 & 94.3 \\
\hline & Private school & 7 & 5.7 \\
\hline
\end{tabular}

In addition to the study group explained in the table, interviews were conducted with 10 preschool teachers within the framework of a semi-structured interview form to explain the quantitative data better. Ten teachers are women who are undergraduate and work in public school. 4 of the teachers have 2 years; 2 teachers have 3 years; 1 teacher has 5 years; 1 teacher has 6 years; 1 teacher has 7 years, and 1 teacher has 16 years of experience.

\section{Data Collection Tool and Validity Reliability}

In this study, the 'Preschool Program Evaluation Scale' developed by Aslan et al. (2016) and the 'Semi-Structured Interview Form' were used by the researchers for teachers' views on the main purpose of the research and sub-problems. Reliability and validity studies of the scale were conducted by Aslan et al. (2019) Reliability coefficient of the scale was determined as .706, input dimension, .796, process dimension .930, and product dimension as .930, for the whole scale it was determined as .925. For the validity of the scale, factor analysis was used. Since the factor loadings of 50 items in the scale were found to be between . 363 and .829 as a result of the factor analysis, it was decided to remain in the scale. The validity of the items is understood from the factor loadings above .32. While the Cronbach Alpha value ranges between .706 and .930 in subscales, the internal consistency coefficient, in general, was determined as .925 (Aslan et al., 2016).

The related literature has been reviewed to develop a semi-structured interview form. On the draft of the interview form, the opinions of 3 members of Gaziantep University that are working in the education and qualitative research fields of the universities were consulted. The necessary corrections were made in line with the answers received as a result of this application and the form was formatted. Later, within the scope of the pilot application, the form was tested on three Preschool teachers who were not included in the sample and were not included in the study, and the functionality of the form was examined by testing whether there were any incomprehensible questions. In the finalized interview form, 16 questions, was asked under the four basic dimensions of the Stufflebeam CIPP model. In this research, Context-Input-Process-Product Evaluation Model [CIPP] proposed by Stufflebeam was used as the program evaluation model. At the point of current situation analysis, it is done in evaluating the context and the environment in which the program is implemented. In the input evaluation dimension, estimated activity plans, stakeholders and materials are evaluated. In process evaluation, the problems encountered in the process are determined by examining how the program is implemented and how the process progresses. The consistency of planned and actual events is also checked during the implementation phase of the program. Finally, in product evaluation, the general and special outcomes of the program, expected and unexpected situations are handled together (Ornstein \& Hunkins, 2004).

One of the questions asked in context is "What are your general views about the program?"; in the input is "What is your level of preparedness regarding the program?"; in the process is "How does your program implementation process work?"; in the product is "What are your views on the evaluation of students?".

The researchers conducted all of the interviews and each interview lasted approximately 30 to 40 minutes. Preferably, a voice recorder was used in cases where the interviewee did not approve; the data were collected using the note-taking technique.

The analyses were made after all the interviews were confirmed to the participants and information was obtained about the accuracy of the results.

\section{Data Analysis}

The data obtained in the quantitative dimension of the study were analyzed using the SPSS package program. Before the analysis, the skewness and kurtosis values were examined to determine whether the data were normally distributed or not, and it was accepted that the data did not show a normal distribution because these values changed between -1.120 and 1.633 (Büyüköztürk, 2010). Since the assumptions were not met, it was decided to use nonparametric tests. The Kruskal Wallis $\mathrm{H}$ test was used to examine whether preschool teachers' views show a significant difference according to the variable of tenure and whether there is a significant difference according to gender, school type, and graduation type with the Mann Whitney $U$ test. Spearman's correlation analysis was performed to determine the relationships between dimensions and a stepwise regression analysis was performed to determine the predictive power of the context, input, and process. In all of the analyses made in the study, the significance level was accepted as $p<.05$ (Büyüköztürk, 2010; Creswell \& Clark, 2017).

In the qualitative dimension of the research, the data were analyzed using content analysis. There are no predetermined themes in this analysis technique. The data collected from the interviews are processed in depth by the researchers and themes are formed. The content analysis aims to provide consistency and establish meaning by reducing and associating data (Patton, 2002). The data collected from the interviews were analyzed according to Stufflebeam's context, input, product, and process approach. Findings obtained from the interviews were expressed with codes such as T1 and T2. The reliability of qualitative data 
Table 2. Teachers' Views on the CIPP Model Dimensions of the Preschool Education Program

\begin{tabular}{|c|c|c|c|c|c|}
\hline Dimension & $\mathbf{n}$ & $\mathbf{x x}$ & SS & Skewness & Kurtosis \\
\hline Context & 122 & 3.29 & .57 & -1.31 & .069 \\
\hline Input & 122 & 3.68 & .74 & -.565 & .761 \\
\hline Process & 122 & 3.99 & .70 & -1.120 & 1.633 \\
\hline Product & 122 & 3.89 & .74 & -.686 & .727 \\
\hline Total & 122 & 3.75 & .55 & -.584 & 1.226 \\
\hline
\end{tabular}

was measured according to the reliability formula of Miles and Huberman (1994). The data were separated into themes and coded by two researchers in the field of curriculum and instruction. The harmony between the studies of these two researchers who made the analysis was determined as .72. Since this value is above the coefficient of .70, it is understood that the data are reliable (Yıldııım \& Şimşek 2018).

\section{RESULTS}

In this part of the study, the CIPP model of the preschool education program was adopted and the findings obtained from the data collected from the evaluations made by the preschool teachers and the content analysis of the interviews were made with the help of a semi-structured interview form.

\section{Findings Regarding the Context, Input, Process, and Product Dimensions of the Preschool Education Program}

As seen in Table 2, the average of the opinions of the teachers regarding the context dimension of the preschool education program is 3.29, the average of the opinions about the input dimension is 3.68 , the average of the opinions about the process dimension is 3.99 and the average of the opinions about the product dimension is 3.89. The average of the views on the whole scale was found to be 3.75 .

It was determined that the teachers stated the most positive opinions about the context dimension and the most positive opinions in the process dimension. When we examine the questions in context, it is concluded that according to the opinions of the teachers, there are not enough tools to organize learning centers and the physical characteristics of the schools are not sufficient for preschool education. Also, the teachers stated that according to quantitative data, regional characteristics were not taken into account in the program.

Considering the opinions of the teachers in the input dimension, it is seen that they generally expressed a positive opinion. It focuses on the items in which the items they expressed the most positive opinion had activities suitable for their level of development and again, the items in which the activities in the program were compatible with the gains. On the other hand, the items with the most negative views stated that the individual differences of the children were taken into account in the program and the family factor was taken into account.

When the product dimension is examined in line with the quantitative data, it is seen that the teachers generally express positive opinions in this dimension.

It is among the findings obtained from the quantitative data that preschool education facilitates the adaptation of children to school and is effective in preparing children for primary school. However, it is the most important problem determined in this dimension that pre-school education is not effective in solving the problems caused by the family.

\section{Findings Regarding the Effect of Duty Time Variable on Teachers' Views Regarding the Quality of Preschool Education Program}

In line with the sub-problems of the study, it was analyzed with the Kruskal Wallis $\mathrm{H}$ test whether there was a difference between the scores the teachers got from the scale according to the variable of duty, and the results are presented in Table 3.

When the data in Table 3 were examined, there was no significant difference between the views of teachers and their tenure in context, process, and product dimensions ( $p>, 05)$. When the data in the input dimension are examined, it is seen that the opinions about the input dimension and the total scale differ statistically significantly according to the duty time variable ( $p<, 05)$.

\section{Findings Regarding the Effect of the Gender Variable on Teachers' Views Regarding the Quality of Preschool Education Program}

In line with the sub-problems of the study, the Mann Whitney $U$ test was used to examine whether there is a significant difference between the scores of the teachers on the scale and the gender variable, and the results are presented in Table 4.

According to the findings of the Mann Whitney $U$ test, which was examined in terms of gender variable, a significant difference was observed between men and women in input, product, and total dimensions. Looking at the average rank, it is seen that the opinions of women in input, product, and total are higher than men. It can be said that a significant difference is observed between men and women in the sum of inputs, products, and results $(p<.05)$. 
Table 3. Kruskal Wallis H Test Results Regarding the Differentiation of the Scores The Teachers Received from the Preschool Education Program Evaluation Scale Regarding the Term of Duty Variable

\begin{tabular}{|c|c|c|c|c|c|c|}
\hline Dimension & Tenure & $\mathbf{N}$ & Rank Averages & Sd & $\mathrm{X}^{2}$ & $\mathbf{P}$ \\
\hline \multirow{4}{*}{ Context } & 1- 5 year & 83 & 61.02 & \multirow{4}{*}{3} & \multirow{4}{*}{3.327} & \multirow{4}{*}{0.344} \\
\hline & 6-10 year & 23 & 69.74 & & & \\
\hline & 11 - 15 year & 12 & 57.08 & & & \\
\hline & 16 - 20 year & 4 & 37.38 & & & \\
\hline \multirow{4}{*}{ Input } & 1- 5 year & 83 & 64.19 & \multirow{4}{*}{3} & \multirow{4}{*}{8.787} & \multirow{4}{*}{0.032} \\
\hline & 6-10 year & 23 & 67.24 & & & \\
\hline & $11-15$ year & 12 & 45.29 & & & \\
\hline & 16 - 20 year & 4 & 21.38 & & & \\
\hline \multirow{4}{*}{ Process } & 1- 5 year & 83 & 61.81 & \multirow{4}{*}{3} & \multirow{4}{*}{4.274} & \multirow{4}{*}{0.233} \\
\hline & 6-10 year & 23 & 67.91 & & & \\
\hline & $11-15$ year & 12 & 57.88 & & & \\
\hline & 16 - 20 year & 4 & 29 & & & \\
\hline \multirow{4}{*}{ Product } & 1- 5 year & 83 & 62.26 & \multirow{4}{*}{3} & \multirow{4}{*}{3.035} & \multirow{4}{*}{0.386} \\
\hline & 6-10 year & 23 & 66.15 & & & \\
\hline & 11 - 15 year & 12 & 56.33 & & & \\
\hline & 16 - 20 year & 4 & 34.5 & & & \\
\hline \multirow{4}{*}{ Total } & 1- 5 year & 83 & 62.63 & \multirow{4}{*}{3} & \multirow{4}{*}{6.458} & \multirow{4}{*}{0.091} \\
\hline & 6-10 year & 23 & 68.5 & & & \\
\hline & 11 - 15 year & 12 & 53.17 & & & \\
\hline & 16 - 20 year & 4 & 22.75 & & & \\
\hline
\end{tabular}

Table 4. Mann Whitney Test Results on the Differentiation of the Preschool Education Program Evaluation Scale by Teachers in terms of Gender Variable

\begin{tabular}{|c|c|c|c|c|c|c|}
\hline Dimension & Group & $\mathbf{N}$ & Rank Averages & Rank Sum & $\mathbf{U}$ & $\mathbf{P}$ \\
\hline \multirow[t]{2}{*}{ Context } & Female & 99 & 64.16 & 6351.50 & \multirow{2}{*}{875.500} & \multirow{2}{*}{.085} \\
\hline & Male & 23 & 50.07 & 1151.50 & & \\
\hline \multirow{2}{*}{ Input } & Female & 99 & 66.86 & 6619.00 & \multirow{2}{*}{608.000} & \multirow{2}{*}{.001} \\
\hline & Male & 23 & 38.43 & 884.00 & & \\
\hline \multirow{2}{*}{ Process } & Female & 99 & 63.95 & 6331.00 & \multirow{2}{*}{896.000} & \multirow{2}{*}{.112} \\
\hline & Male & 23 & 50.96 & 1172.00 & & \\
\hline \multirow{2}{*}{ Product } & Female & 99 & 64.99 & 6434.50 & \multirow{2}{*}{792.500} & \multirow{2}{*}{.023} \\
\hline & Male & 23 & 46.46 & 1068.50 & & \\
\hline \multirow[t]{2}{*}{ Total } & Female & 99 & 65.92 & 6526.00 & \multirow{2}{*}{701.000} & \multirow{2}{*}{.004} \\
\hline & Male & 23 & 42.48 & 977.00 & & \\
\hline
\end{tabular}

Table 5. Mann Whitney Test Results on the Differentiation of the Preschool Education Program Evaluation Scale by Teachers in terms of School Type Variable

\begin{tabular}{|c|c|c|c|c|c|c|}
\hline Dimension & Group & $\mathbf{N}$ & Rank Averages & Rank Sum & $\mathbf{U}$ & $\mathbf{P}$ \\
\hline \multirow[t]{2}{*}{ Context } & State school & 115 & 60.02 & 6902.50 & \multirow{2}{*}{232.500} & \multirow{2}{*}{.061} \\
\hline & Private school & 7 & 85.79 & 600.50 & & \\
\hline \multirow{2}{*}{ Input } & State school & 115 & 61.55 & 7078.00 & \multirow{2}{*}{397.000} & \multirow{2}{*}{.952} \\
\hline & Private school & 7 & 60.71 & 425.00 & & \\
\hline \multirow{2}{*}{ Process } & State school & 115 & 60.68 & 6978.00 & \multirow{2}{*}{308.000} & \multirow{2}{*}{.298} \\
\hline & Private school & 7 & 75.00 & 525.00 & & \\
\hline \multirow{2}{*}{ Product } & State school & 115 & 61.84 & 7112.00 & \multirow{2}{*}{363.000} & \multirow{2}{*}{.663} \\
\hline & Private school & 7 & 55.86 & 391.00 & & \\
\hline \multirow[t]{2}{*}{ Total } & State school & 115 & 61.18 & 7036.00 & \multirow{2}{*}{366.000} & \multirow{2}{*}{.688} \\
\hline & Private school & 7 & 66.71 & 467.00 & & \\
\hline
\end{tabular}

\section{Findings Regarding the Effect of the School Type Variable on Teachers' Views Regarding the Quality of Preschool Education Program}

The Mann-Whitney $U$ test was used to examine whether there is a significant difference between the type of school studied and the scores the teachers got from the scale, another sub-problem of the study, and the results are presented in Table 5.

When the findings related to the Mann-Whitney $U$ test are examined, it is seen that there is no significant difference between the views according to the school type variable.

Considering the rank averages, although the opinions of the teachers in the private school are higher in terms of context, process, and total dimensions, and the input and product dimensions of the teachers working in the public school, no significant difference was observed between them ( $p>.05)$. 
Table 6. Mann Whitney Test Results on the Differentiation of the Preschool Education Program Evaluation Scale by Teachers in Terms of Graduation Type Variable

\begin{tabular}{|c|c|c|c|c|c|c|}
\hline Dimension & Group & $\mathbf{N}$ & Rank Averages & Rank Sum & $\mathbf{U}$ & $\mathbf{P}$ \\
\hline \multirow[t]{2}{*}{ Context } & Undergraduate & 113 & 61.01 & 6894.00 & \multirow{2}{*}{453.000} & \multirow{2}{*}{.586} \\
\hline & Postgraduate & 9 & 67.67 & $609, .00$ & & \\
\hline \multirow{2}{*}{ Input } & Undergraduate & 113 & 61.55 & 6955.00 & \multirow{2}{*}{503.000} & \multirow{2}{*}{.957} \\
\hline & Postgraduate & 9 & 60.89 & 548.00 & & \\
\hline \multirow{2}{*}{ Process } & Undergraduate & 113 & 61.42 & 6940.50 & \multirow{2}{*}{499.500} & \multirow{2}{*}{.930} \\
\hline & Postgraduate & 9 & 62.50 & 562.50 & & \\
\hline \multirow{2}{*}{ Product } & Undergraduate & 113 & 62.90 & 7108.00 & \multirow{2}{*}{350.000} & \multirow{2}{*}{.120} \\
\hline & Postgraduate & 9 & 43.89 & 395.00 & & \\
\hline \multirow[t]{2}{*}{ Total } & Undergraduate & 113 & 61.92 & 6997.50 & \multirow{2}{*}{460.500} & \multirow{2}{*}{.638} \\
\hline & Postgraduate & 9 & 56.17 & 505.50 & & \\
\hline
\end{tabular}

Table 7. Spearman Correlation Analysis Results Related to the Relationship Between Sub-Dimensions of the Preschool Education Program Evaluation Scale

\begin{tabular}{|c|c|c|c|c|}
\hline Dimension & Input & Process & Product & Total \\
\hline Context & $.481^{\star \star}$ & $.443^{\star \star}$ & $.557^{\star \star}$ & $.745^{\star \star}$ \\
\hline Input & - & $.471^{\star \star}$ & $.595^{\star \star}$ & $.807^{\star \star}$ \\
\hline Process & - & - & $.597^{\star \star}$ & $.787^{\star \star}$ \\
\hline Product & - & - & - & $.865^{\star \star}$ \\
\hline
\end{tabular}

\section{Findings Regarding the Effect of the Graduation Type Variable on Teachers' Views Regarding the Quality of Preschool Education Program}

Finally, the Mann-Whitney $U$ test was used to examine whether there is a significant difference between the education level that the teachers graduated from and the scores the teachers got from the scale and the results are presented in Table 6.

When the findings regarding the Mann-Whitney $U$ test are examined, it is seen that there is no significant difference between the opinions according to the graduation type variable. Considering the rank averages, although the scores of graduate teachers in context and process dimensions are higher and the scores of graduate teachers in input, product, and total dimensions are higher, no statistically significant difference was found between them ( $p>.05)$.

\section{Findings Regarding the Relationships Between Preschool Education Program's CIPP Context, Input, Process, and Product} Dimensions

The results of the Spearman correlation analysis performed to determine the relationships between dimensions (Context, Input, Process, Product) are given in Table 7. Spearman correlation analysis was used to examine the relationship between context, input, process and product dimensions in analyzing the data, since the data did not show normal distribution.

When Table 7 is examined, it is seen that there is a positive significant relationship between scale dimensions $(p<$. It is seen that there is a medium level $(r=.481)$ significant relationship between context and input dimensions, a medium level $(r=.443)$ between context and process dimensions, and a medium level $(r=.557)$ relationship between context and product dimensions. It is seen that there is a medium level $(r=.471)$ significant relationship between input and process dimensions, and a medium level $(r=.595)$ significant relationship between input and product dimensions. Finally, there is a moderate $(r=.597)$ positive significant relationship between the process and product dimensions.

The data obtained as a result of the interviews with the teachers were analyzed and the findings were gathered around 18 themes. During the interviews, four questions about the context dimension were asked to the teachers. Themes and codes of this size are given in Table 8. 
Table 8. The Theme and Codes of the Context Dimension of Teachers' Views

\begin{tabular}{|c|c|c|}
\hline Theme & Code & Frequency (f) \\
\hline \multirow{10}{*}{ Program Opportunities } & Flexibility & 5 \\
\hline & Holistic approach & 6 \\
\hline & Individual differences & 6 \\
\hline & Compliance with the level of development & 8 \\
\hline & Family involvement & 10 \\
\hline & Program values & 9 \\
\hline & Suitable for level & 7 \\
\hline & Student-centered & 5 \\
\hline & Spiral & 4 \\
\hline & Game-based & 6 \\
\hline \multirow{9}{*}{ Program Threats } & Inequality of opportunity & 5 \\
\hline & Ignoring individuality & 5 \\
\hline & Practitioner inadequacies & 3 \\
\hline & Physical disabilities & 6 \\
\hline & Insufficient publicity & 8 \\
\hline & Adaptation & 7 \\
\hline & Standard program & 7 \\
\hline & Not mandatory & 5 \\
\hline & Don't care & 6 \\
\hline \multirow{10}{*}{ The purpose of the program } & Preparing for primary school & 6 \\
\hline & Supporting development & 4 \\
\hline & Language development & 7 \\
\hline & Opportunity Equality & 2 \\
\hline & Preparing for life & 4 \\
\hline & Getting good habits & 2 \\
\hline & Intelligence Development & 2 \\
\hline & Be a good citizen & 4 \\
\hline & Adaptation & 6 \\
\hline & Self-care skills & 5 \\
\hline
\end{tabular}

As shown in the table, the codes of flexibility and holistic approach under the theme of program opportunities; under the theme of program threats, physical disabilities, and inequality codes come to the fore.

Flexibility and holistic approach under the theme of program opportunities; under the theme of program threats, some quotations about physical disabilities and inequality of opportunities are given below.

T2: "The program has been prepared by taking into account the individual differences of children in general. And it has flexibility according to the environmental conditions of the applied school. One of the weak points of the program is that some of the activities in the program sometimes do not comply with the conditions economically and physically. "

Four questions were asked to the teachers regarding the input evaluation dimension of the program. Themes and codes of this size are given in Table 9.

In the context of this evaluation, the research group asked the teachers "What do you think about the entrance characteristics/readiness levels of the students?" The question has been asked.

As can be seen in the table, the family factor, the influence of the environment, and low-level codes came to the fore in the theme of readiness. In the interviews with the teachers, the family factor, the effect of the environment, low, high, moderate, positive change, gender variable, insufficient stimulus, not being ready, health problem, psychological problems, variable structure, and socio-economic conditions were obtained.

Below are some quotations from teachers who expressed their views on the family factor, the influence of the environment, and the low level of readiness.

T4: "Most of them are missing. Many children come to school without meeting with books and pencils, without being perceived as individuals, and without a chat environment. He doesn't develop many of the features he needs to improve until he gets to school. "

Teachers who indicate many factors on this subject state that their students generally have a low level of readiness due to the effect of the family factor. 
Table 9. The Theme and Codes of the Input Dimension of Teachers' Views

\begin{tabular}{|c|c|c|}
\hline Theme & Code & Frequency (f) \\
\hline \multirow{13}{*}{ Readiness } & Family factor & 5 \\
\hline & Environmental influence & 5 \\
\hline & Low degree & 6 \\
\hline & High degree & 3 \\
\hline & Moderately & 8 \\
\hline & Positive change & 8 \\
\hline & Gender variable & 9 \\
\hline & Insufficient stimulus & 7 \\
\hline & Not being ready & 6 \\
\hline & Health problem & 6 \\
\hline & Psychological problems & 6 \\
\hline & Variable & 7 \\
\hline & Socio-economic conditions & 5 \\
\hline \multirow{8}{*}{ Proximity to the Program } & At an adequate level & 8 \\
\hline & Insufficient in-service training & 8 \\
\hline & Individual effort & 7 \\
\hline & Reinforce with experience & 5 \\
\hline & Adequate in-service training & 9 \\
\hline & Open to development & 8 \\
\hline & Participation in seminars & 5 \\
\hline & Virtual environment & 2 \\
\hline
\end{tabular}

Table 10. The Theme and Codes of the Process Dimension of Teachers' Views

\begin{tabular}{|c|c|c|}
\hline Theme & Code & Frequency (f) \\
\hline \multirow{30}{*}{ Teaching Methods and Techniques } & Drama & 8 \\
\hline & Show and get done & 5 \\
\hline & Expression & 5 \\
\hline & Educational game & 7 \\
\hline & Question-answer & 4 \\
\hline & Station technique & 4 \\
\hline & Show & 6 \\
\hline & Brainstorming & 6 \\
\hline & Experiment & 6 \\
\hline & Parent involvement & 5 \\
\hline & Observation & 8 \\
\hline & travel & 8 \\
\hline & Problem-solving & 7 \\
\hline & Project-based learning & 4 \\
\hline & Simulation & 4 \\
\hline & Child-centered & 5 \\
\hline & Experience & 4 \\
\hline & Discussion & 5 \\
\hline & Case study & 6 \\
\hline & Six hats & 6 \\
\hline & Roleplay & 7 \\
\hline & Fishbone & 4 \\
\hline & Story-tale telling & 6 \\
\hline & Cornering & 5 \\
\hline & Circle & 5 \\
\hline & Multiple intelligence methods & 8 \\
\hline & Learning by living leaves & 7 \\
\hline & Science and nature activity & 5 \\
\hline & Model & 5 \\
\hline & Cooperative learning & 5 \\
\hline
\end{tabular}

In this context, the teachers who are the subject of the research were first asked "How does your program implementation process work?" The question has turned. All of the teachers stated that they applied the daily education flow in the program. Below are some quotations from teachers for the daily education flow.

T5: "Welcoming the students - free time - gathering and circle time - cleaning - food - cleaning - activity time - going home. Sometimes garden hours are added depending on the situation. "

Although there are changes in the training flow, all of the teachers stated that they follow the daily training flow specified in the program. Within the scope of this dimension, five questions were asked to the interviewed teachers. The codes and themes discussed in this dimension are given in Table 11. 
Table 11. Themes and Codes of the Product Dimension of Teachers' Views

\begin{tabular}{|c|c|c|}
\hline Theme & Code & Frequency (f) \\
\hline \multirow{15}{*}{ Evaluation process } & Individual assessment & 8 \\
\hline & Holistic assessment & 8 \\
\hline & Portfolio & 8 \\
\hline & Systematic evaluation & 7 \\
\hline & Observing behavior & 5 \\
\hline & Process evaluation & 8 \\
\hline & Self-assessment & 4 \\
\hline & Control List & 6 \\
\hline & Observation techniques & 6 \\
\hline & Insufficient measurement & 7 \\
\hline & Survey evaluation & 6 \\
\hline & Incompatibility of progress reports & 5 \\
\hline & Evaluation according to the development area & 6 \\
\hline & Product evaluation & 4 \\
\hline & Family involvement & 8 \\
\hline \multirow{19}{*}{ Program Expectations } & Improving physical conditions & 9 \\
\hline & Compulsory pre-school education & 5 \\
\hline & Opportunity Equality & 5 \\
\hline & The importance of the program & 4 \\
\hline & Holistic development area & 6 \\
\hline & Stimulating material & 6 \\
\hline & Renewal of reports & 7 \\
\hline & Associating with life & 6 \\
\hline & Game intensive program & 7 \\
\hline & Individuality based & 6 \\
\hline & Need for control & 6 \\
\hline & The problem with the hierarchy & 4 \\
\hline & In-service training & 5 \\
\hline & Support units & 4 \\
\hline & School-family cooperation & 5 \\
\hline & Few students & 6 \\
\hline & Should be detailed & 7 \\
\hline & Development of reports & 8 \\
\hline & Increasing the materials & 5 \\
\hline
\end{tabular}

The first of these questions is "To what extent does the program meet your / your students' expectations and needs?" As can be seen in the table, adequate and positive desired level codes stand out in this question. In the interviews with the teachers, sufficient, positive, partially positive, compensatory, and improvement opinions were obtained.

The teachers interviewed stated that the program met their expectations and needs at a sufficient level; 7 of them stated that they contributed positively to student development. Some quotations that support these views are given below.

T8: "I think it meets the expectations and needs at a sufficient level. The fact that the students who are not included in the program have different levels of behavioral and academic achievements in the first year reveals the importance of the program once again."

According to the data obtained, teachers stated that the program meets the needs at an adequate level and contributes positively to student development.

\section{DISCUSSION, CONCLUSION, AND RECOMMENDATIONS}

In this study, it was aimed to evaluate the pre-school education program according to the CIPP model, which is one of the curriculum evaluation models in line with the opinions of the teachers working at the pre-school education level. When the views of the teachers in the context dimension are examined, it is seen that the averages of the views are below the averages of the other dimensions. It was concluded that the physical characteristics of the schools are not sufficient for pre-school education. In the research conducted by Kubanç (2014), it was revealed that the schools had physical infrastructure deficiencies and that the schools were largely not built according to the determined standards. From the interviews with the teachers, it was concluded that the necessary opportunities were not provided for the implementation of the preschool education program. It was found that this situation did not meet the needs of both students and teachers. However, in parallel with this situation, in the evaluation study of the preschool program conducted by Aslan and Uygun (2019) according to the CIPP model, it was revealed that the teachers working in the villages were more pessimistic than the teachers working in the provinces and districts. For this reason, in order for the updated programs in the Turkish Education System to be implemented effectively, it is necessary to eliminate financial deficiencies and improve the conditions of the schools in the villages. In addition, in a study by Mercan Uzun and Alat (2014) including primary school teachers, it was found that teachers working in villages found the cognitive fitness of children low. In the study conducted by Düzgün (2014), it was argued that teachers in schools with low socio-economic level have less opportunity to implement many necessary activities than those in prestigious schools. 
In the interviews with the teachers in the context dimension, it was concluded that according to the answers given by the teachers, the program met the student needs equally adequately and insufficiently. In the qualitative interviews, it was concluded that the majority of the teachers were aware of the aims of the program regarding the question of the purpose of the program. Köksal et al. (2016) also obtained findings that support this result. According to this research, the pre-school education program has been stated by most teachers, as it is a program with positive features, easy to apply, flexible, and covers all development areas, meeting the needs to a great extent.

Considering the input dimension in general, it was seen that the teachers expressed positive opinions. It was observed that the opinions obtained in this dimension focused on the view that the activities implemented in the program were appropriate for the development level. Looking at the results obtained from the qualitative data in this dimension, it was concluded that especially the family factor has an important effect on the entrance characteristics of the students. In the interviews, teachers expressed negative opinions in general contrary to quantitative data. It was emphasized that the activities could not be held due to lack of materials and the desired gains could not be achieved, but generally supplementary resources were sufficient.

Köksal et al. (2016) found that family participation studies are not at a sufficient level in preschool institutions. Teachers, on the other hand, found their level of closeness to the program generally high. In addition, from the interviews with the teachers, it was concluded that the materials and resources were insufficient to achieve the program goals in general. It was concluded that some of the teachers provided materials with their efforts. While they found the training related to the program insufficient, they stated that they achieved these levels with their efforts. In a study conducted by Uşun and Cömert (2003), it was determined that they were willing to receive in-service training on 'plans implemented in pre-school education institutions'. However, in the qualitative interviews, teachers stated that there was no in-service training offered to them regarding the program.

When the quantitative data on the process dimension was examined, it was concluded that the teachers stated the most positive opinions in this dimension. Teachers' opinions about the process dimension are at a positive level. It was concluded that the teachers were generally satisfied with the process and the applications. MoNE (2013) stated that the pre-school education program is flexible and the gains are means, not goals, giving teachers freedom in this regard. Teachers' shaping their practices according to the needs of their classes can be effective in expressing positive opinions in this dimension. It was concluded that teachers in this dimension preferred the active learning method in their activities. In the interviews with the teachers, who are involved in the education of the younger age group, stated that they mostly use techniques in which the students are active. The opinion was obtained that teachers organize their learning environments according to their needs.

Regarding the product dimension, considering the quantitative data, generally, positive opinions were obtained from the teachers in this dimension. According to the findings obtained from the quantitative data, it was concluded that preschool education facilitates the adaptation of children to school. In the study conducted by Koçyiğit (2009), when teachers were describing a child ready for primary school, they expressed the expression 'child who received pre-school education', which supports these findings. It was concluded that the program was not at a sufficient level in solving family-related problems. In the interviews, teachers emphasized that the program generally contributed positively to student development, contributed to the preparation for primary school and adaptation to school, but didn't contribute to the family and this situation prevented the solution of family-related problems. However, there are many studies in the literature regarding the positive effects of family participation on the development of children (Gürşimşek, 2003; Hindman \& Morrison, 2012; Jeynes, 2015)

In the qualitative data, from the interviews with the teachers, it was concluded that the program met the needs adequately and had a positive effect on student development. In the interviews with the teachers, it was concluded that they made individual evaluations taking into account individual differences in the evaluation of students in terms of products.

While some of the teachers stated that the measurement and evaluation processes were sufficient to take into account individual differences, some of them stated that they ignored superficial and individual differences. Although it is determined that multidimensional and individual assessment is applied by teachers, as stated in the pre-school education program of MONE (2013), it is stated that some of the teachers have difficulties in making an individual and multidimensional assessment.

Considering the limitations and results, the following recommendations are made:

- In order to be more effective, an education program that appeals to the development area of children and the cultural level of the families and offers more stimulating materials should be developed in general with better economic conditions.

- Pre-school education should be made compulsory.

- A program should be developed that appeals more to the individual differences of children and that children learn by doing and experiencing.

\section{Limitations}

It is thought that mentioning the limitations of this study in this section is important in terms of revealing the difference of the study from other studies based on the CIPP model. It will also help to understand the difference of the study from the pre-school curriculum evaluation studies presented by Aslan and Uygun (2019).

This study has certain limitations in the following points. If the limitations stated in this scope are removed, it is anticipated that they will guide researchers who will carry out similar program evaluation studies.

1. This study is limited to the data collected in the 2019-2020 academic year.

2. This study has limitations due to data from semi-structured interviews prepared by researchers and data obtained from the scale used with Aslan et al. (2016) permission.

3. This study is limited by the opinions of preschool teachers who work in some provinces in Turkey. 
4. This study was not over-attended by preschool teachers due to the COVID19 pandemic and is limited to the data provided by 122 preschool teachers to the scale.

Funding: No funding source is reported for this study.

Declaration of interest: No conflict of interest is declared by author.

\section{REFERENCES}

Akdağ, H. (2008). Implementation of Primary School $6^{\text {th }}$ and $7^{\text {th }}$ Grade Social Studies Curriculum in terms of Teachers and Students (Publication no: 227887) (Doctoral Dissertation), Gazi University, Turkey.

Aktan, S. (2015). John Franklin Bobbitt’te program düşüncesinin gelişimi: Tarihsel bir inceleme. International Periodical for the Languages, Literature and History of Turkish or Turkic., 10(15), 35-50. https://doi.org/10.7827/TurkishStudies.8893

Arslan, M. (2009). Eğitim Bilimine Giriş [Introduction to Educational Science]. Ankara: Gündüz Eğitim ve Yayıncılık.

Aslan, M., \& Uygun, N. (2019). Okul öncesi eğitim programının Stufflebeam'in bağlam, girdi, süreç ve ürün (BGSÜ) değerlendirme modeline göre değerlendirilmesi [Evaluation of pre-school education program according to Stufflebeam's context, input, process and product (BGSÜ) evaluation model]. Eğitim ve Bilim, 44(200), 229-251.

Aslan, M., Soyalp, H., Karahan, O., \& Altuntaş, M. (2016). The development of preschool curriculum evaluation scale. YYU Journal of Education Faculty, 1(13), 657-683.

Aydoğan, Y. (2006). Reorganizing the home environment for child's development. Journal of Social Policy Studies, 3(10), 27-33.

Büyüköztürk, Ş. (2010). Veri Analizi El Kitabı [Data Analysis Handbook] (12nd Ed.). Ankara: Pegem Akademi.

Creswell, J. W. (2013). Research Design: Qualitative, Quantitative, and Mixed Methods Approach (4th Ed.). Thousand Oaks, CA: Sage

Creswell, J. W., \& Clark, V. L. P. (2017). Designing and Conducting Mixed Methods Research. Sage publications.

Currie, J. (2001). Early childhood education programs. Journal of Economic Perspectives, 15(2), $213-238$. https://doi.org/10.1257/jep.15.2.213

Demirel, Ö. (2017). Eğitimde Program Geliştirme [Program Development in Education]. Ankara: Pegem Akademi.

Düzgün, Ü. (2014). Okul Öncesi Öğretmenlerinin Okul Öncesi Eğitim Programı ve 2012 Değişikliklerinin Uygulanmasına ilişskin Görüşleri (Kayseri ili Örneği) [Preschool Teachers' Opinions on the Pre-school Education Program and the Implementation of the 2012 Changes (Kayseri Province Sample)] (Unpublished master's thesis). Erciyes University, Institute of Educational Sciences, Kayseri, Turkey.

Erişen, Y. (1998). Program Geliştirme Modelleri Üzerine Bir İnceleme. Retrieved April $13^{\text {th }}, 2020$ from https://www.pegem.net/dosyalar/dokuman/109011-20120211141216-erisen.pdf.

Ertürk, S. (2013). Eğitimde Program Geliştirme [Program Development in Education] (6th Ed.). Ankara: Edge Akademi.

Fitzpatrick, J. L., Sanders, J. T., \&Worthen, B. R. (2004). Program Evaluation: Alternative Approaches and Practical Guidelines (3rd Ed.). Boston: Allyn and Bacon.

Glassman, M. (2001). Dewey and Vygotsky: Society, experience, and inquiry in educational practice. Educational Researcher, 30(4), 3-14. https://doi.org/10.3102/0013189X030004003

Green, J., C., Krayder, H., \& Mayer, E. (2005). Combining qualitative and quantitative methods in social inquiry. In B. Somekh \& C. Lewin (Eds.), Research Methods in the Social Sciences (pp. 275-282). London: Sage.

Gürşimşek, I. (2003). Okul öncesi eğitime aile katılımı ve psikososyal gelişim [Family participation and psychosocial development in pre-school education]. Kuram ve Uygulamada Eğitim Bilimleri-Educational Sciences: Theory and Practice, 3(1), 125-144.

Hindman, A. H., \& Morrison, F. J. (2012). Differential contributions of three parenting dimensions to preschool literacy and social skills in a middle-income sample. Merrill-Palmer Quarterly, 58(2) 191-223. https://doi.org/10.1353/mpq.2012.0012

Jeynes, W. (2015). A meta-analysis: The relationship between father involvement and student academic achievement. Urban Education, 50(4), 387-423. https://doi.org/10.1177/0042085914525789

Karasar, N. (2016). Bilimsel Araştırma Yöntemi [Scientific Research Method]. Ankara: Nobel Akademik Yayıncılık.

Karataş, H. (2007) Evaluation of the syllabus of English II instruction program in modern languages departments, Yıldız Technical University via the opinions of the teachers and students using context, input, process, and product (CIPP) model. (Publication no. 205619) (Masters' thesis), Yıldız Technical University, Turkey.

Klenowski, V. (2010). Curriculum evaluation: Approaches and methodologies. In P. Peterson, E. Baker, \& B. McGaw (Eds.), International Encyclopedia of Education (pp. 335-341). Elsevier. https://doi.org/10.1016/B978-0-08-044894-7.00069-5

Koçak, G. H. (2006). The problems of computer technology and programming education program. (Publication no. 206084) (Masters' thesis), Cukurova University, Turkey.

Koçyiğit, S. (2009). First-grade teachers and parents' views about the phenomenon of school readiness and its implications for preschool education (Publication no. 234780) (Doctoral dissertation), Selcuk University, Turkey.

Köksal, O., Dağal, A. B., \& Duman, Ö. A. (2016). The determination of pre-school teaching program in accordance with pre-school teacher opinions. The Journal of Academic Social Science Studies, 4, 379-394. 
Kol, S. (2011). Cognitive development and language development in early childhood. The Journal of SAU Education Faculty, 21(May 2011), 1-21.

Kubanç, Y. (2014). Physical examinations of the state of preschool education institutions. Journal of International Social Research, 7(31).

Mercan Uzun, E., \& Alat, K. (2014). Illkokul birinci sınıf öğretmenlerinin 4+ 4+ 4 eğitim sistemi ve bu sistem sonrasında ilkokula başlayan öğrencilerin hazır bulunuşlukları hakkındaki görüşleri [Primary school first grade teachers' opinions on the $4+4+4$ education system and the readiness of students who started primary school after this system]. Abant Izzet Baysal Üniversitesi Eğitim Fakültesi Dergisi-Abant Izzet Baysal University Journal of Education Faculty, 14(2), 15-44. https://doi.org/10.17240/aibuefd.2014.14.2-5000091526

Miles, M. B., \& Huberman, A. M. (1994). Qualitative data analysis: An expanded sourcebook. Sage.

Ministry of National Education. (2013). Okul Öncesi Eğitim Programı [Preschool Education Program]. Retrieved on 13 April 2020 from https://tegm.meb.gov.tr/dosya/okuloncesi/ooproram.pdf

Mother Child Education Foundation. (2003). "Erken Çocukluk Eğitimi Politikaları: Yaygınlaşma, Yönetişim ve Yapılar Toplantısı" Raporu ["Early Childhood Education Policies: Dissemination, Governance and Structures Meeting" Report]. Retrieved 13 April 2020 from https://acev.org/wp-content/uploads/2017/11/erken_cocukluk_egitimi_politikalari_yayginlasma_yonetisim_ yapilar_toplantisi.pdf

Nance, R. (2009). The importance of early childhood education. Roles of Play, Language, Socialization, Formation of Values. Quest Paper.

Oral, B., \& Yazar, T. (2017). Eğitimde Program Geliştirme ve Değerlendirme [Program Development and Evaluation in Education]. Ankara: Pegem. https://doi.org/10.14527/9786052410509

Ornstein, A. C., \& Hunkins, F. P. (2004). Curriculum: Foundations, principles and issues. Boston: Pearson/Allyn and Bacon.

Patton, M. Q. (2002). Qualitative Research and Evaluation Methods (3rd Ed.). Thousand Oaks, CA: Sage.

Royse, D., Thyer, B. A., \& Padgett, D. K. (2009). Program Evaluation: An Introduction. Cengage Learning.

Sarangapani, P. M. (2006). The Tyler Paradox. Contemporary Education Dialogue, 4(1), $119-141$. https://doi.org/10.1177/0973184913411134

Sholihah, M., Purnawirawan, O., \& Puspita, C. P. (2020). Application of evaluation model to analyze the implementation of clean and healthy life behavior program on practice subject of culinary arts program. Journal of Vocational and Career Education, $5(2), 74-80$.

Steele, S. (1975). An emerging concept of program evaluation. Journal of Extension, 13(2), 13-22.

Stufflebeam, D. L., \& Coryn, C. L. S. (2014). Evaluation, Theory, Model / Applications (2nd Ed.). San Francisco: Jossey-Bass.

Subedi, D. (2016). Explanatory sequential mixed method design as the third research community of knowledge claim. American Journal of Educational Research, 4(7), 570-577.

Uşun, S., \& Cömert, D. (2003). The identification of pre-school teachers needs for in-service training. Gazi University Journal of Gazi Educational Faculty (GUJGEF), 23(2), 125-138.

Yaşar Ekici, F. (2017). The relationship between social skills and problem behaviors of the children that their families involve and do not involve in the family involvement activities implemented in preschool education institutions. Hitit University Journal of Social Sciences Institute, 10(1), 543-562. https://doi.org/10.17218/hititsosbil.299033

Yıldırım, A., \& Şimşek, H. (2018). Sosyal Bilimlerde Nitel Araştırma Yöntemleri [Qualitative Research Methods in the Social Sciences] (11th Ed.). Ankara: Seçkin Press. 